\title{
Positive selection on sperm ion channels in a brooding brittle star: consequence of life-history traits evolution
}

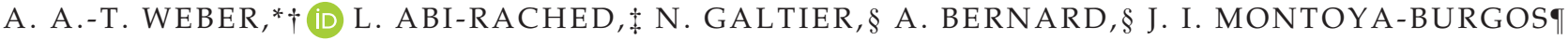 \\ and A. CHENUIL* \\ *Institut Méditerranéen de Biodiversité et d'Ecologie marine et continentale (IMBE) - CNRS - IRD - UAPV, Aix-Marseille \\ Université, Station Marine d'Endoume, Chemin de la Batterie des Lions, 13007 Marseille, France, †Zoological Institute, \\ University of Basel, Vesalgasse 1, 4051 Basel, Switzerland, †Equipe ATIP, URMITE UM 63 CNRS 7278 IRD 198 Inserm \\ U1095, IHU Méditerranée Infection, Aix-Marseille Université, Marseille, France, §UMR 5554 Institut des Sciences de \\ l'Evolution, CNRS, IRD, EPHE, Université de Montpellier, Place E. Bataillon 34095 Montpellier, France, qDepartment of \\ Genetics and Evolution, University of Geneva, 4, Bvd d'Yvoy, 1205 Geneva, Switzerland
}

\begin{abstract}
Closely related species are key models to investigate mechanisms leading to reproductive isolation and early stages of diversification, also at the genomic level. The brittle star cryptic species complex Ophioderma longicauda encompasses the sympatric broadcast-spawning species $\mathrm{C} 3$ and the internal brooding species $\mathrm{C} 5$. Here, we used de novo transcriptome sequencing and assembly in two closely related species displaying contrasting reproductive modes to compare their genetic diversity and to investigate the role of natural selection in reproductive isolation. We reconstructed 20146 and 22123 genes for C3 and C5, respectively, and characterized a set of 12229 orthologs. Genetic diversity was 1.5-2 times higher in C3 compared to C5, confirming that species with low parental investment display higher levels of genetic diversity. Forty-eight genes were the targets of positive diversifying selection during the evolution of the two species. Notably, two genes (NHE and TetraKCNG) are sperm-specific ion channels involved in sperm motility. Ancestral sequence reconstructions show that natural selection targeted the two genes in the brooding species. This may result from an adaptation to the novel environmental conditions surrounding sperm in the brooding species, either directly affecting sperm or via an increase in male/female conflict. This phenomenon could have promoted prezygotic reproductive isolation between $\mathrm{C} 3$ and C5. Finally, the sperm receptors to egg chemoattractants differed between C3 and C5 in the ligand-binding region. We propose that mechanisms of species-specific gamete recognition in brittle stars occur during sperm chemotaxis (sperm attraction towards the eggs), contrary to other marine invertebrates where prezygotic barriers to interspecific hybridization typically occur before sperm-egg fusion.
\end{abstract}

Keywords: ion channel, marine invertebrate, reproductive isolation, sperm chemotaxis, sperm competition, transcriptome

\section{Introduction}

Understanding mechanisms leading to the formation of new species is a fundamental question in evolutionary biology. In particular, how reproductive barriers evolve, and what the genetic basis of barriers to gene flow is, remain enigmatic for many nonmodel organisms (Noor \& Feder 2006; Nosil \& Schluter 2011; Ellegren 2014). Thanks to their recent divergence, closely related species are fascinating models to study the mechanisms leading to reproductive isolation and ultimately speciation (Seehausen et al. 2014). It is generally expected that while global genetic divergence between recently 
diverged species will be low, genes involved in reproductive isolation, also called 'speciation genes', will display higher levels of differentiation (Nosil \& Schluter 2011; Nosil \& Feder 2012).

When different species live in the same geographic location (i.e. in sympatry), mechanisms preventing genetic exchange between species can occur before or after the fusion of gametes. Therefore, these mechanisms are classified as prezygotic or postzygotic factors of reproductive isolation, respectively. While postzygotic isolation leads to death or sterility of the newly formed embryos due to genomic incompatibilities (i.e. BatesonDobzhansky-Muller incompatibilities), prezygotic isolation can include, for instance, temporal prezygotic isolation, where reproduction periods are not overlapping. In marine invertebrates, where the sense of sight is limited to photoreception, mechanisms of species recognition are mostly mediated through chemical signals (Palumbi 1994). For instance, there can be active avoidance of nonconspecific males and females, via chemical signals, to avoid interspecific mating (Hendler 1991; Bickford et al. 2007; Mercier \& Hamel 2009). Finally, when closely related species occur in sympatry, genes involved in gamete recognition can evolve under positive diversifying selection and display increased genetic differentiation, therefore preventing the recognition of gametes belonging to different species and their fusion (Lessios 2011; Vacquier \& Swanson 2011).

The most famous examples of gamete recognition proteins are the sperm protein bindin and its egg receptor EBR1 in sea urchins, and the sperm protein lysin and its egg receptor VERL in gastropods. The bindin is a protein involved in the recognition between the sperm and the egg vitelline envelope, as well as in the fusion of sperm and egg membranes. In contrast, the lysin is only involved in recognition and dissolution of the vitelline envelope, the fusion of sperm and egg membrane being mediated by the protein sp18 (Lessios 2011; Vacquier \& Swanson 2011). Positive selection frequently targets these systems, as was shown for the bindin protein in sea urchins of the genus Strongylocentrotus, Paracentrotus, Heliocidaris and Echinometra (Lessios 2011), as well as in sea stars (Sunday \& Hart 2013; Patiño et al. 2016), and for the egg receptor for sperm Obi1 (Hart 2013; Hart et al. 2014). Similarly, the proteins involved at the level of egg jelly and in particular their carbohydrate-recognition domains (suREJ) were found to be under positive diversifying selection in six species of sea urchins (Mah et al. 2005). This receptor interacts with sulphated polysaccharides to induce the acrosome reaction, polysaccharides which also display structural changes between closely related species of Strongylocentrotus sea urchins (Biermann et al. 2004). Prezygotic isolation through gamete recognition therefore seems to be the rule in sea urchins and likely sea stars, but whether this mechanism is general to echinoderms, and more generally to marine invertebrates, is still unclear.

With more than 2000 extant species, brittle stars (Ophiuroidea) form the largest class of echinoderms. Brittle stars occur in virtually every marine environment, from very shallow to abyssal depths, and from tropical to Arctic and Antarctic areas (Stöhr et al. 2012). Interestingly, this class includes numerous complexes of cryptic species, among which morphological characters are poorly or not (yet) differentiated (Baric \& Sturmbauer 1999; Sponer \& Roy 2002; O'Hara et al. 2004; Muths et al. 2006, 2009; Boissin et al. 2008, 2011; Hunter \& Halanych 2008; Stöhr et al. 2009; Heimeier et al. 2010; Stöhr \& Muths 2010; Hoareau et al. 2013; Pérez-Portela et al. 2013; Naughton et al. 2014; de Moura Barboza et al. 2015; Taboada \& Pérez-Portela 2016).

The brittle star cryptic species complex Ophioderma longicauda is composed of six divergent mitochondrial lineages displaying contrasting reproductive strategies (broadcast spawners and internal brooders; Stöhr et al. 2009; Boissin et al. 2011). This species complex, encompassing at least three distinct biological species, occurs in the East Atlantic Ocean and in the Mediterranean Sea. In the so-called broadcast spawners (the ancestral strategy), reproduction occurs once a year, fertilization is external and larvae experience a dispersive pelagic phase of about 6 days (Fenaux 1969, 1972). In contrast, in the brooding species (the derived strategy), fertilization is presumably internal, embryos develop for several weeks in female-specific pouches (bursae; Stöhr et al. 2009), and dispersal occurs only at the adult stage. The two reproductive systems presumably imply contrasted selective pressures at the gametic stage, which might impact the mechanism and evolution of prezygotic isolation. Here, we focused on two sympatric species from the O. longicauda complex, named temporarily C3 (broadcast spawner) and C5 (internal brooder) until formal description is completed (S. Stöhr, A.A.-T. Weber, E. Boissin, A. Chenuil, in preparation). These two species, in addition to displaying different reproductive strategies, do not reproduce at the same time of the year and display genetic, ecological, physiological and morphological differences (Weber et al. 2013, 2014, 2015). There is currently no gene flow between C3 and C5, and their divergence time is estimated to about 550000 years (Weber 2015). Thus, this pair of closely related species provides an interesting model system to investigate reproductive isolation and genome differentiation. We used transcriptome sequencing and de novo assembly to compare the genetic diversity and investigate the role of natural selection in the reproductive isolation between $O$. longicauda C3 and C5. In contrast with sea urchins, we found 
that in O. longicauda, proteins associated to gamete recognition are not particularly fast evolving. Yet, we identified two genes associated to sperm motility, which were positively selected in the brooding species.

\section{Material and methods}

\section{Individual sampling, lineage typing and RNA extraction}

Sampling was performed in four localities across the Mediterranean and the Atlantic (Madeira, Greece, Portugal and France; Table S1, Supporting information). For each individual, gonads, embryos (when present) and a piece of arm were preserved in RNA later and later used for RNA extraction (Table S1, Supporting information); a piece of arm was also preserved in EtOH 95\% for DNA extraction using a Chelex protocol (Walsh et al. 1991). Species delimitation was performed according to the mitochondrial lineages described by Boissin et al. (2011). For each specimen, a COI gene fragment was PCR-amplified (forward primer: 5' CTT GCA GGA GGA GGA GAY CC 3'; reverse primer: 5' AGT ATA AGC GTC TGG GTA GTC $3^{\prime}$ ) and Sangersequenced (LGC Genomics, Germany). Individuals from Madeira, Sagres and Marseille belonged to the broadcasting species C3 (mitochondrial lineage L1 in Boissin et al. (2011)), whereas individuals from Crete represented species C3 and C5 (mitochondrial lineages L1 and L3, respectively), in line with the species distribution described by Weber et al. (2015). To illustrate the presence of two distinct species, phylogenetic trees for $\mathrm{COI}$ and for the nuclear marker EF1 $\alpha$ (Elongation factor $1 \alpha$; retrieved from the transcriptomes generated in this study) are available in Fig. S1, Supporting information. RNA extractions were performed using a combination of standard guanidium thiocyanate-phenol-chloroform (GTPC) RNA extraction followed by an extra purification step with a RNeasy kit for RNA extractions (Qiagen). Both methods were used in combination with maximize quantity and purity of RNA, as recommended by Gayral et al. (2011). Twelve libraries for RNA sequencing were prepared (Table S1, Supporting information); seven with RNA from unique individuals (two from species C5 and five from species C3) and five with RNA from pooled individuals from four different localities (C5-Crete, C3-Crete, C3-France, C3-Madeira, C3-Portugal). Pools of individuals were performed using the same quantity of RNA per individual.

\section{Sequencing and assembly}

Library preparation and sequencing were performed by the genomic platform Genotoul (Toulouse). Libraries were constructed using TruSeq library preparation kit (Illumina) following manufacturer's instructions. Sequencing was performed with a Hiseq 2000 sequencer (Illumina). The complete bioinformatics pipeline used in this study is described in Gayral et al. (2013). For this assembly, only the individual libraries were used, to calculate the per-species nucleotide diversity and the individual heterozygosities. Briefly, raw reads were filtered for length $(\geq 60 \mathrm{bp}$ ) and quality (Phred score $\geq 30$ ). De novo assembly was performed using Abyss (Simpson et al. 2009) and Cap3 (Huang \& Madan 1999), according to the method B described in (Cahais et al. 2012). The combination of Abyss and Cap3 was selected based on a combination of reliability and computational efficiency. In addition, this combination was recently shown to perform better than Trinity in the assembly of 26 species of plants (Sarah et al. 2016). Reads were mapped to the contigs using BWA (Li \& Durbin 2009). Raw contigs were filtered for length $(\geq 200 \mathrm{bp})$ and coverage $(2.5 \times$ per individual). ORFs were predicted from the filtered contigs, and the longest ORF was kept. Genotypes were called for each position of each contig using read2SNPs and applying a filter for hidden paralogy as described in Gayral et al. (2013). Genotypes were only called if supported by a posterior probability above 0.95 and at least 10 reads. For each species, the per-site synonymous $\left(\pi_{\mathrm{S}}\right)$ and nonsynonymous $\left(\pi_{\mathrm{N}}\right)$ diversities were calculated, as well as the per-individual heterozygosity.

\section{Research and annotation of orthologs}

Orthologs between C3 and C5 were predicted using a reciprocal best BLAST hit approach, similarly to Gayral et al. (2013). BLASTP searches were performed using the $13990 \mathrm{C} 3 \mathrm{ORFs}$ as query and the $20790 \mathrm{C} 5 \mathrm{ORF}$ as target, and vice versa with an e-value cut-off of $10 \mathrm{e}^{-5}$. Results with no hit, with an overlap $<60 \%$ or with an identity percentage $<90 \%$ were discarded. In addition, results with a ratio of the score of the second best hit over the score of the best hit higher than 0.8 were removed, to avoid the inclusion of paralogs. This analysis yielded 4740 putative orthologs, a surprisingly low number for two species so closely related. A potential problem seemed to be the low number of ORFs retrieved for the broadcasting species C3: because we used the same methodology for sample preparation and sequencing, we hypothesized that this problem stemmed from a combination of high polymorphism in C3 and too much stringency in the coverage criterion.

To test this possibility, we attempted to recover C3 contigs using C5 contigs as references for mapping, and vice versa. To maximize the chances of recovering lost contigs, all the reads of each species were used (from 
single and pooled individuals) and coverage constraints were relaxed. C3 reads were mapped on the 11405 C5 contigs displaying less than $80 \%$ identity with C3 contigs after the first BLAST search using BOWTIE2 (Langmead \& Salzberg 2012), and allowing a maximum of five differences (for 100-bp reads) with the reference contig to account for the fact the reads and the reference belong to two different species. C3 contigs were then reconstructed using MIRA (Chevreux et al. 1999). Contigs with gaps in the coverage, or with an average coverage $<10 \times$ or smaller than $250 \mathrm{bp}$, were discarded. A reciprocal best BLAST hit analysis was then performed to compare the newly reconstructed C3 contigs to the 20790 C5 contigs and to verify whether these newly reconstructed C3 contigs indeed corresponded to some of the original C5 references. Using this method, 6156 additional C3 contigs were reconstructed, raising the total number of C3 contigs to 20 146. The equivalent analysis for C5 led to the reconstruction of 1333 additional C5 contigs, raising the total number of $\mathrm{C} 5$ contigs to 22 123. Comparison of the $20146 \mathrm{C} 3$ contigs to the 22123 C5 contigs using a reciprocal best BLAST hit approach isolated a set of 12229 orthologs. To ensure that the C3-C5 comparison only involved orthologous contigs, we used the ratio between the first and the second best BLAST hit score as a guide, and contigs with a ratio $>0.8$ were excluded.

Functional annotation was performed via BLASTP against the NR (nonredundant) database of NCBI using an e-value cut-off of $10 \mathrm{e}^{-5}$. The top 20 hits were extracted and loaded in BLAST2GO for annotation (Conesa et al. 2005). Mapping, annotation and slim ontology were performed with BLAST2GO using default parameters, except for the annotation cut-off parameter that was set to 45 . GO categories were described using the level 3 of slim ontology. For the genes that did not display GO term annotations, BLASTP search was performed against the NR (nonredundant) database of NCBI using an $e$-value cut-off of $10 \mathrm{e}^{-5}$.

\section{Positively selected genes and gamete recognition genes}

To characterize genes evolving under positive diversifying selection, we performed a first screen using the pipeline PSGfinder (Montoya-Burgos laboratory: https://genev.unige.ch/research/laboratory/Juan-Mon toya). This pipeline performs standard pairwise $\mathrm{dN} / \mathrm{dS}$ calculation using a pair of aligned nucleotide sequences of orthologous protein-coding genes (one consensus sequence per species). The $\mathrm{dN} / \mathrm{dS}$ ratio is calculated for alignment windows which size is determined by the presence of at least three nonsynonymous substitutions; this provides a sufficient $\mathrm{dN}$ starting signal that reduces the number of windows to be tested. The estimation of $\mathrm{dN}$ and $\mathrm{dS}$ values were obtained using the method 'yn00' (Yang \& Nielsen 2000), including its assumptions, as implemented in PAML version 4.8 (Yang 2007). Windows with a $\mathrm{dN} / \mathrm{dS}$ ratio $>1$ were considered as indicative of gene parts displaying a signal of positive diversifying selection. The advantage of PSGfinder is that it uses pairwise comparison of orthologs, so positively selected candidate genes can be found even when only two species are available. Then, we confirmed that the most interesting candidate genes found with PSGfinder displayed signals of positive diversifying selection using a codon substitution model [modified branch-site model A; Bayes Empirical Bayes (BEB) analysis; O. longicauda C5 as foreground branch] of codeml implemented in PAML version 4.8 (Yang 2007), using outgroup sequences from public databases (sea urchin S. purpuratus) or kindly provided by Timothy O'Hara (brittle stars Ophiothrix angulata and Ophiophragmus wurdemani). Because of its change in reproductive mode, we expect the genes of the brooding species C5 to have evolved under positive selection. As control, we also performed the same analysis but using O. longicauda C3 as foreground branch (where we do not expect positive selection to occur). In addition, we used the recently developed BUSTED method which allows to identify genewide evidence of episodic positive selection (Murrell et al. 2015), implemented in the HYPHY package (Pond \& Muse 2005). Furthermore, we used the branchsites random effects likelihood method which allows to detect lineages evolving under positive selection without an a priori hypothesis (Pond et al. 2011), also implemented in the HYPHY package (Pond \& Muse 2005). Finally, we used ancestral sequence reconstruction methods (marginal reconstruction method; WAG amino acid replacement matrix) implemented in PAML version 4.8 (Yang 2007) to confirm which species was affected by natural selection.

Several proteins involved in reproduction (in sperm chemotaxis or in sperm-egg interaction) and whose evolution in other species involved diversifying selection were specifically isolated in our C3 and C5 contigs using BLASTP searches. These proteins were the bindin and its receptor EBR1, as well as the sperm receptor for egg jelly, suREJ, involved in activation of the acrosome reaction, sperm-activating peptides from S. purpuratus (speract) and from Asterias amurensis (asterosap) as well as their associated receptors (speract receptor and asterosap receptor), known to induce sperm chemotaxis. For the egg receptor for sperm Obi1, we used the sequence of the sea star Patiria miniata as query. We also searched for C3/C5 homologs of the sperm-specific calcium channels (Catsper 1-4) known to evolve under positive selection in rodents (Podlaha et al. 2005) and primates (Podlaha \& Zhang 2003). 


\section{Results}

Assembly statistics and annotation of orthologous genes

Illumina sequencing provided about 250 million raw reads, which were trimmed for length and quality-filtered. Assembly yielded 523565 and 259916 raw contigs for C3 and C5, respectively (Table 1). After filtering for length and coverage, 110225 C3 and 118043 C5 filtered contigs were obtained. Open reading frame prediction yielded 13990 and 20800 ORFs for C3 and C5, respectively. After ORF reconstruction based on 'unique' genes of each species, we obtained 20146 and 22123 ORFs for C3 and C5, respectively, of which 12229 were clearly orthologous genes (Fig. 1). The average nucleotide divergence of the 12229 orthologs

Table 1 Transcriptome assembly statistics generated in study

\begin{tabular}{|c|c|c|}
\hline & $\begin{array}{l}\text { C3 } \\
\text { (5 individuals) }\end{array}$ & $\begin{array}{l}\text { C5 } \\
\text { (2 individuals) }\end{array}$ \\
\hline Raw reads & 164464891 & 87959550 \\
\hline Raw contigs & 523565 & 259916 \\
\hline Filtered contigs & 110225 & 118043 \\
\hline ORFs & 13990 & 20790 \\
\hline Reconstructed ORFs & 20146 & 22123 \\
\hline Orthologous genes & 12229 & 12229 \\
\hline Annotated orthologous genes & 5925 & 5925 \\
\hline
\end{tabular}

\section{Brooding species C5 Broadcasting species C3}

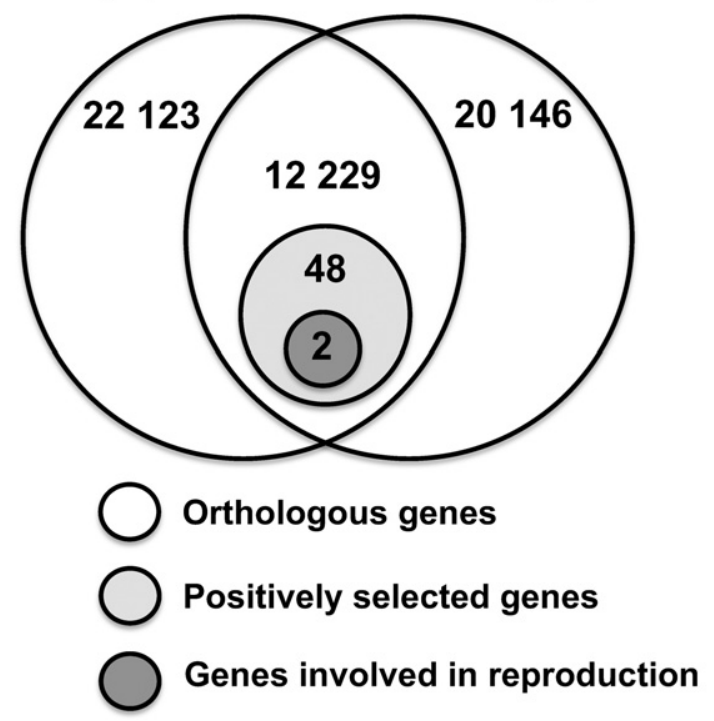

Fig. 1 Summary of the gene number, orthologous gene number and positively selected genes between Ophioderma longicauda C3 and C5 found in this study. at the nucleotide level was $0.93 \%$. The higher number of genes in C5 might partly be due to the fact that developing embryos were included in the species $\mathrm{C} 5$ transcriptomes, contrary to the species $\mathrm{C} 3$ that was not sexually mature at the time of sampling.

Of the 12229 identified orthologs, 5925 (48\%) could be successfully annotated with GO terms. For biological process, primary metabolic process was the most abundant GO term $(10.8 \%)$, followed by organic substance metabolic process $(10.6 \%)$ and cellular metabolic process $(8.1 \%)$ (Fig. S2, Supporting information). For molecular function, genes coding for binding were highly represented $(67.8 \%)$ as well as transferase $(10.5 \%)$ and hydrolase (12.9\%) activities (Fig. S2, Supporting information).

\section{Broadcast spawners display higher genetic diversity compared to brooders}

To investigate genetic diversity, 1388 and 6700 genes were used for $\mathrm{C} 3$ and $\mathrm{C} 5$, respectively (Table 2). The smaller number of genes in C 3 is most likely due to the stringent quality thresholds applied for genotype calling. Indeed, a position had to be covered with at least 10 reads per individual in order to be called. Given that the C3 individuals were not sampled at the same time of the year nor in the same localities (Table S1, Supporting information), they most likely displayed differences in gene expression levels and therefore differences in gene coverage. Using only $\mathrm{C} 3$ individuals from Crete (e.g. same locality as C5), we retrieved more than 5000 genes for the analysis, which gave the same diversity estimates as with the data set of 1388 genes (data available upon request). A total of 7607 and 18408 SNPs were called for $\mathrm{C} 3$ and $\mathrm{C} 5$, respectively. The average per-site synonymous diversity $\left(\pi_{\mathrm{S}}\right)$ was about twice

Table 2 Comparison of transcriptomic genetic diversity between broadcasting $\mathrm{C} 3$ and brooding $\mathrm{C} 5$ species

\begin{tabular}{llll}
\hline & & & $\begin{array}{l}\text { Diversity } \\
\text { ratio } \\
\text { C3 } / \mathrm{C} 5\end{array}$ \\
\hline Reproductive strategy & Broadcasters & Brooders & \\
N individuals & 5 & 2 & \\
N contigs & 1388 & 6700 & \\
N SNPs & 7607 & 18408 & \\
Average $\pi_{\mathrm{S}}\left[\times 10^{-3}\right]$ & 17 & 8 & 2.12 \\
$\begin{array}{l}\text { Average } \pi_{\mathrm{N}} / \pi_{\mathrm{S}} \text { ratio } \\
\text { Average heterozygosity }\end{array}$ & 0.181 & 0.269 & 0.67 \\
{$\left[\times 10^{-3}\right]( \pm \mathrm{SD})$} & & $4.16( \pm 0.2)$ & 1.51 \\
\hline
\end{tabular}

SNPs, single nucleotide polymorphisms; Sd, standard deviation; $\pi_{\mathrm{S}}$, synonymous nucleotide diversity; $\pi_{\mathrm{N}}$, nonsynonymous nucleotide diversity. 
higher in C3 compared to C5, resulting in a higher $\pi_{\mathrm{N}} / \pi_{\mathrm{S}}$ ratio in C5 (Table 2). In addition, the average heterozygosity was about 1.5 higher in C3 compared to C5.

\section{Sperm-specific ion channels exhibit positive diversifying selection}

Comparison of the 12229 orthologs between the species C3 and C5 isolated 187 sequence windows displaying evidence of positive diversifying selection (PSGfinder, dNwindow/dSgene $>1, P$-value $<0.001$ ). These 187 windows were contained in 48 distinct genes, eleven of which could be successfully annotated with GO terms (Table 3). Another 17 of the 48 genes could be linked to biological process such as immunity, DNA transcription and phosphorylation through BLAST searches (Table S2, Supporting information); $45 \%(5 / 11)$ of the annotated genes encode proteins involved in ion transport, which is a significant enrichment compared to the global transcriptome annotation (3.6\%; 215/5925). Interestingly, two genes involved in ion transport are well characterized functionally: the sperm-specific sodium-proton exchanger (NHE) and the tetrameric potassium-selective cyclic nucleotide gated channel (TetraKCNG) (Fig. 1, Table 3).

Positive selection analyses performed with PAML were concordant with the results of PSGfinder, with the majority of the positively selected sites retrieved with PAML were also observed in regions detected with PSGfinder (19/26; Figs 2 and 3). In addition, ancestral sequence reconstructions revealed that positive diversifying selection particularly targeted the TetraKCNG and NHE genes in the brooding species C5 (Figs 2 and 3). Interestingly, for both genes, $>75 \%(21 / 27)$ of the positively selected sites detected by PAML and divergent in the brooding species are conserved in all other species, even in the distantly related sea urchin Strongylocentrotus purpuratus (Figs 2 and 3). Finally, the BUSTED method confirmed that both genes are evolving under positive selection (NHE: $P$-value $=0.00422$; TetraKCNG: $P$-value $=0.0235)$, whereas only NHE was confirmed using the branch-sites random effects likelihood method (NHE: $P$-value $=0.016$; TetraKCNG: $P$-value $=1$ ).

NHE and TetraKCNG are well studied in the sea urchin S. purpuratus and are involved in sperm motility after activation of sperm with chemoattractants released by the eggs, such as speract [Fig. 4; see (Darszon et al. 2008) for the complete speract signalling model]. If sperm chemoattractants are species specific, they may be different between the brooding and the broadcasting species. To our knowledge, sperm chemoattractants are not described in brittle stars. Therefore, we attempted to find an ortholog of sperm chemoattractant in brittle stars based on the ones described in the literature, which are speract (in the sea urchin S. purpuratus) and asterosap (in the sea star $A$. amurensis). Unfortunately, we could not identify any ortholog, likely because of the small size of the peptides (ten amino acids for speract and 56 amino acids for asterosap; Hirohashi et al. 2008; Nakachi et al. 2008). As ligand and receptor are likely to co-evolve, we isolated the sequences of the sperm chemoattractant receptor in the two O. longicauda species (guanylyl cyclase) but comparison of the two sequences did not reveal any evidence of positive diversifying selection (Table 4). Interestingly, however, of the ten nonsynonymous mutations found in the sperm chemoattractant receptor gene, nine occur in the extracellular (ligand-binding) part, whereas none are detected in the transmembrane part and only one is found in the intracellular part. In addition, a four-codon gap was found in the ligand-binding part of C5, suggesting that C3 and C5 may display different sperm chemoattractants. Therefore, mechanisms of species recognition could occur during sperm chemotaxis in the Ophioderma longicauda species complex. Finally, we found orthologs of the proteins involved in fertilization of Bindin, EBR1, suREJ1, Catsper 1-4, ARIS 1-3, Obi1 and Rendezvin. Yet, the evolution of these proteins did not reveal any evidence of positive diversifying selection in O. longicauda C3 and C5 (Table 4).

\section{Discussion}

\section{Genetic diversity is lower in brooders}

In this study, we used transcriptomes of two sympatric brittle stars belonging to the species complex Ophioderma longicauda to compare their level of genetic diversity and investigate how natural selection targeted genes potentially involved in their reproductive isolation. Genetic diversity, a central metric in species response to environmental disturbance (Reusch et al. 2005; Hughes et al. 2008), is about 1.5-2 times higher in the broadcasting species C3 compared to the brooding species C5, despite low average nucleotide divergence $(<1 \%)$. These results are in line with a recent study investigating genetic diversity of 76 metazoan species, which showed that the main determinant of genetic diversity is parental investment (Romiguier et al. 2014). In particular, species categorized as K-strategists (high longevity, high parental investment, low number of large offspring) displayed lower genetic diversity than r-strategists (low longevity, low parental investment, high number of small offspring). These strategies highlight different responses of species to environmental disturbances (MacArthur \& Wilson 1967). In this context, the brooding O. longicauda C5 might be more 


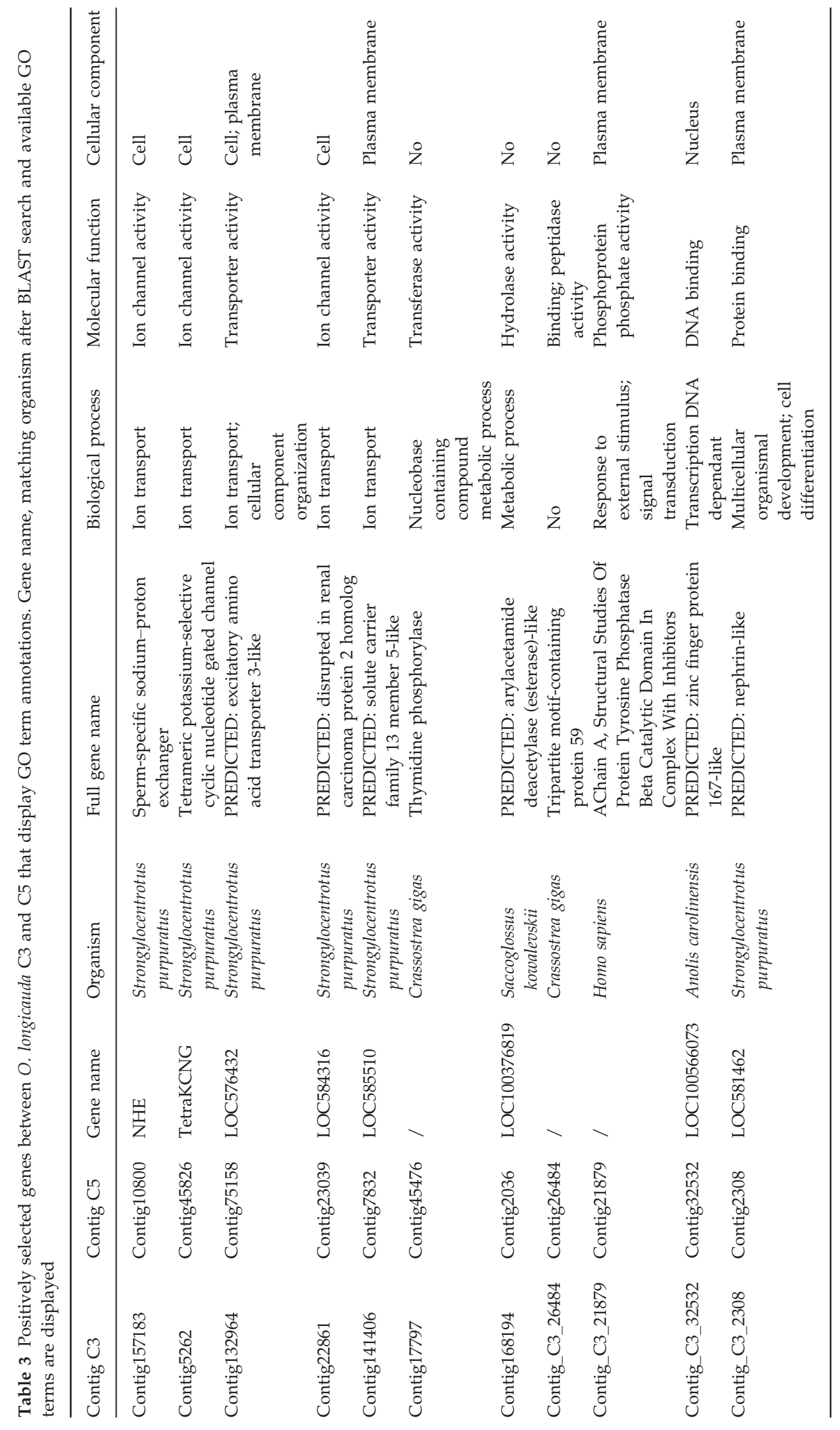


51

Ophioderma_C5
Ophioderma_C3
Ophioderma_ancestral
ophiothrix_angulata
Strongylocentrotus_purpuratus

TWMMVFNYLC

AWMMVFNYLC ELVFIFEIYI

DAITANYL ELVFIFEIYI

strongylocēentrotus_purpuratus

Ophioderma_c5

Ophioderma_c3

Ophioderma_ancestral

ophiothrix_angulata

strongylocentrotus_purpuratus
101 r

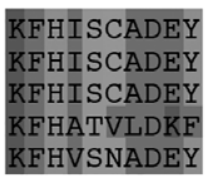

MYQAFYQVQS

\begin{tabular}{|l|l|l|l|l|} 
FLDLAASIP & LEILALCFPE & GHMFKAFTCF & RLTRLIRFIR & VNQFFSNWEK \\
FALDLVASIP & LEVFALCFPG & GHVFKAFTCF & RLTRLIRFIR & VNOFFSNWEK \\
FALDLVASIP & LEIFALCFPG & GHMFKAFTCF & RLTRLIRFIR VNOFFSNWEK \\
FAVDCFGTIP & FEFFAVFVSP & ESMFAVYSTL & RLTRLIRLIR & VMOYFSSWEK \\
FAODLIPTLP & IELFAFLAOG & DKOFAVLSFL & RFROVIRLMR VSOFFDRWEQ \\
\hline
\end{tabular}

Ophioderma C5

Ophioderma_c3

151 is

ophioderma_ancestral

ophiothrix_angulata

strongylocēentrotus_purpuratus

\begin{tabular}{|c|c|c|c|c|}
\hline ELDIDMLKV & LTKMLVIVTM & IIHIFI & MI & VGSWVEKHD \\
\hline ELDIDMLKVR & LTKMFVFVTM & IIHIFASIWY & MIACPLDECK & VGSWVDDADY \\
\hline ELDIDMLKVR & LTKMFVFVTM & IIHIFASIWY & MIACPLDECK & VGSWVDDHDY \\
\hline ELDINMLKVR & LTKMLFVITM & VIHICASIWY & ALACPLAECK & EGSWAEVOGY \\
\hline ELNINILKVR & LTKFLVLLLI & IIHLFASIWY & TIACPLSNCK & NGSWATMMG \\
\hline
\end{tabular}

Ophioderma_C5

ophioderma_C3

ophioderma-ancestral

ophiothrix_angulata

strongylocentrotus_purpuratus

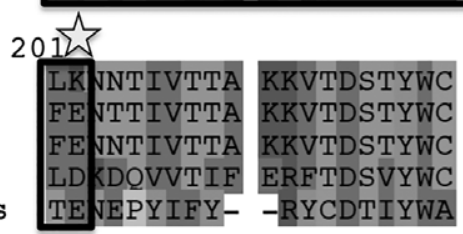

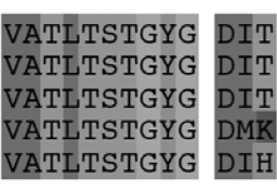

Region evolving under positive diversifying selection (PSGfinder)

Fig. 2 TetraKCNG protein alignment including Ophioderma longicauda C3 and C5, as well as outgroups Ophiothrix angular (brittle star) and Stronglylocentrotus purpuratus (sea urchin). Ancestral sequence reconstruction of Ophioderma was performed with PAML version 4.8. The region evolving under positive selection detected by PSGfinder and the positively selected sites detected by PAML are displayed. The alignment highlights that positive diversifying selection occurred in the brooding species Ophioderma longicauda C5. Levels of grey correspond to different amino acid families.

vulnerable to rapid environmental changes than the broadcasting $\mathrm{O}$. longicauda $\mathrm{C} 3$.

\section{Mechanisms of prezygotic isolation}

We focused on genes displaying positive Darwinian selection involved in reproduction, because they may have played a role in reproductive isolation of $O$. longicauda brooding and broadcasting species. There are several steps leading to fertilization in free-spawning invertebrates: (i) sperm chemotaxis, which is the activation and attraction of sperm mediated by chemoattractants released by the egg, (ii) interaction of sperm with the egg jelly, which induces the acrosome reaction, (iii) binding of sperm to egg vitelline envelope, (iv) penetration of sperm through the egg envelope and (v) fusion of gamete membranes (Vacquier 1998). So far, positively selected proteins contributing to prezygotic isolation in marine invertebrates were involved in sperm-egg interactions, either at the level of egg jelly (step ii) with the sperm receptors suREJ (Mah et al. 2005) or at the level of vitelline layer binding and penetration (steps iii-iv) with the sperm protein bindin (Lessios 2011; Vacquier \& Swanson 2011; Evans \& Sherman 2013), as also shown recently for sea stars (Patiño et al. 2016). In Ophioderma longicauda, none of these proteins were found to evolve under positive selection. Interestingly, we could sequence and assemble, to our knowledge, the first bindin sequences of brittle stars, which displayed very low divergence between the brooding and the broadcasting species. Using domain prediction analyses, we did not detect any repetitive regions as found in sea stars (Patiño et al. 2016). It is therefore likely that the Ophioderma bindin sequences are incomplete, due to the difficulty of assembling repetitive regions using short read sequences. Further research on brittle star bindin should be 


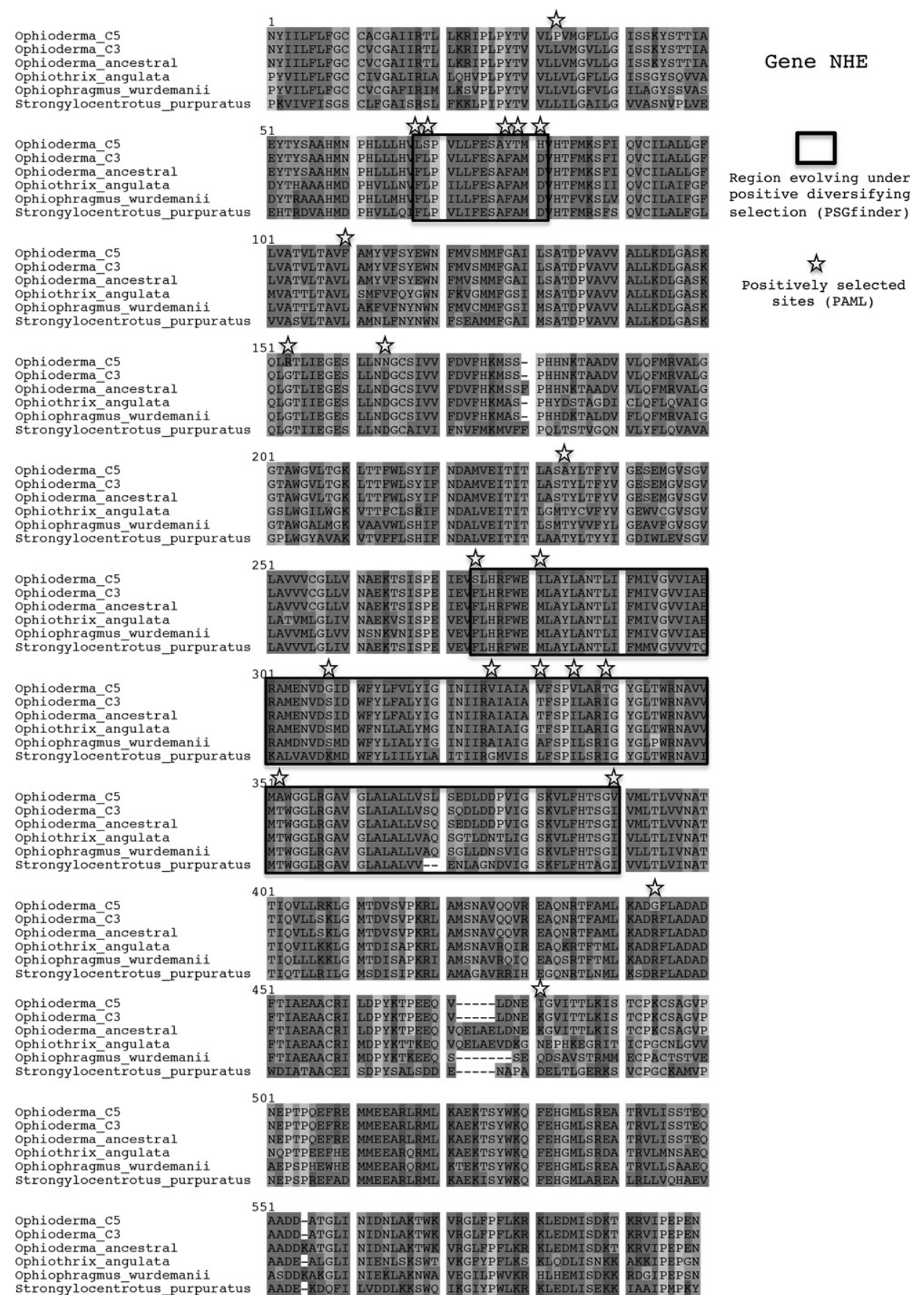

Fig. 3 NHE protein alignment including Ophioderma longicauda C3 and C5, as well as outgroups Ophiothrix angulata (brittle star), Ophiophragmus wurdemanii (brittle star) and Stronglylocentrotus purpuratus (sea urchin). Ancestral sequence reconstruction of Ophioderma was performed with PAML version 4.8. The region evolving under positive selection detected by PSGfinder and the positively selected sites detected by PAML are displayed. The alignment highlights that positive diversifying selection occurred in the brooding species Ophioderma longicauda C5. Levels of grey correspond to different amino acid families.

performed to conclude on the role of bindin in species recognition and speciation.

In contrast, positive selection was found to act on two ion channels involved in sperm activation and motility. Interestingly, these genes have never been described as being positively selected between closely related species so far. The two sperm-specific ion channels (TetraKCNG and NHE) and their involvement in sperm activation have been extensively studied in sea urchins (Beltrán et al. 2007; Galindo et al. 2007; Darszon 


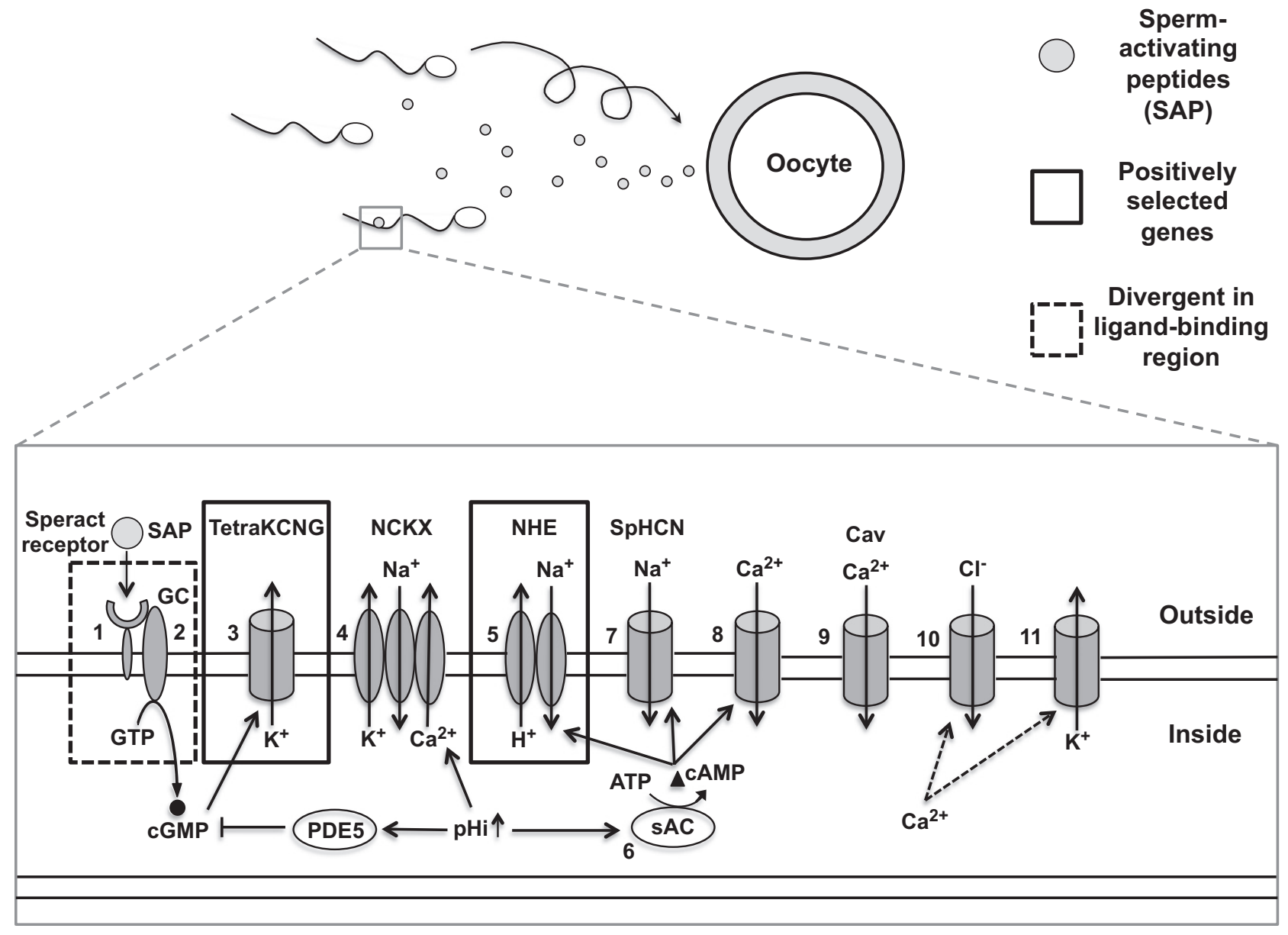

Fig. 4 Speract signalling model (modified from Darszon et al. 2008). In the sea urchin, Strongylocentrotus purpuratus, the sperm-activating peptides (SAP) speract, released by the eggs, bind to speract receptor (1) and activate a guanylyl cyclase (GC), which activates sperm motility through changes in intracellular cGMP (2), pH (3-5), cAMP (6-7) and calcium concentration (8-11). Sperm is attracted to the eggs along a gradient of chemoattractants (sperm chemotaxis). The positively selected genes (NHE and TetraKCNG) in O. longicauda C3 and C5 are highlighted. In the sea star Asterias amurensis, the SAP asterosap bind directly to the guanylyl cyclase to activate sperm motility. This is also likely the case in brittle stars, which are more closely related to sea stars compared to sea urchins. In O. longicauda C3 and C5, the guanylyl cyclase orthologs are divergent in the ligand-binding region (nine nonsynonymous mutations and one-four-codon gap), suggesting the existence of different chemoattractants in C3 and C5. Reproduced with permission from The International Journal of Developmental Biology (Int. J. Dev. Biol.) (2008) Vol: 52595-606.

et al. 2008). In addition, the $\mathrm{Na}+\mathrm{H}+$ exchanger (NHE) is also involved in the signalling of the acrosome reaction (Beltrán et al. 2007). NHE is essential for sperm motility, as shown with NHE-null male mice which displayed severely diminished sperm motility (Wang et al. 2003). Yet, the exact mechanism explaining how mutations at the protein level influence the movement of ions remains to be investigated. Interestingly, positive selection was also found to occur in other sperm-specific ion channels, Catsper (1-4), which are involved in sperm motility in primates and rodents (Podlaha \& Zhang 2003; Podlaha et al. 2005). These four channels, also found in O. longicauda, did not display signals of positive selection, contrary to TetraKCNG and NHE.
Positive selection on putative sperm motility genes: consequence of brooding evolution?

Although fertilization has not been directly observed in brooding O. longicauda, fertilization is very likely to occur internally, within the brooding pouches. Furthermore, all brooding females contained juveniles at a single stage of development (Weber et al. 2014), in favour of a single fertilization event. Several hypotheses were investigated to explain positive selection on ion channels TetraKCNG and NHE: (i) brooding conditions per se, (ii) male/female conflict, (iii) sexual selection via sperm competition and (iv) reinforcement, the most convincing hypotheses being (i) and (ii). 
Table 4 List of known genes involved in gamete recognition and fertilization in echinoderms (Strongylocentrotus purpuratus, Patiria miniata and Asterias amurensis) and their occurrence in Ophioderma longicauda C3 and C5 transcriptomes. Unless specified, BLAST was performed using sequences from Strongylocentrotus purpuratus

\begin{tabular}{|c|c|c|c|c|c|c|}
\hline Gene & Function & Contig name & $\begin{array}{l}\text { BLAST result } \\
\text { (\%ID and } \\
\% \text { coverage })\end{array}$ & $\begin{array}{l}\text { Divergence } \\
\text { C3-C5 [nt/ } \\
\text { protein \%] }\end{array}$ & $\begin{array}{l}\text { Positively } \\
\text { selected }\end{array}$ & References \\
\hline Speract & $\begin{array}{l}\text { Sperm chemoattractant from } \\
\text { S. purpuratus }\end{array}$ & $\begin{array}{l}\text { C3: no hit } \\
\text { C5: no hit }\end{array}$ & - & - & - & $\begin{array}{l}\text { Hansbrough \& } \\
\text { Garbers (1981) }\end{array}$ \\
\hline Asterosap* & $\begin{array}{l}\text { Sperm chemoattractant from } \\
\text { A. amurensis }\end{array}$ & $\begin{array}{l}\text { C3: no hit } \\
\text { C5: no hit }\end{array}$ & - & - & - & $\begin{array}{l}\text { Nakachi et al. } \\
\text { (2008) }\end{array}$ \\
\hline $\begin{array}{l}\text { Speract } \\
\text { receptor }\end{array}$ & $\begin{array}{l}\text { Guanylyl cyclase, involved in } \\
\text { activation of sperm motility }\end{array}$ & $\begin{array}{l}\text { C3: Contig16770 } \\
\text { C5: Contig35656 }\end{array}$ & $57-93$ & {$[1 / 1.4]$} & No & $\begin{array}{l}\text { Dangott \& Garbers } \\
\text { (1984) }\end{array}$ \\
\hline $\begin{array}{l}\text { Asterosap } \\
\text { receptor* }\end{array}$ & $\begin{array}{l}\text { Guanylyl cyclase, receptor to } \\
\text { sperm chemoattractant and } \\
\text { activation of sperm motility }\end{array}$ & $\begin{array}{l}\text { C3: Contig16770 } \\
\text { C5: Contig35656 }\end{array}$ & $72-56$ & {$[1 / 1.4]$} & No & $\begin{array}{l}\text { Nakachi et al. } \\
\text { (2008) }\end{array}$ \\
\hline Catsper1 & $\begin{array}{l}\text { Sperm-specific calcium channel } \\
\text { involved in sperm motility }\end{array}$ & $\begin{array}{l}\text { C3: Contig69549 } \\
\text { C5: Contig55755 }\end{array}$ & $56-96$ & {$[0.8 / 1.1]$} & No & Ren et al. (2001) \\
\hline Catsper2 & $\begin{array}{l}\text { Sperm-specific calcium channel } \\
\text { involved in sperm motility }\end{array}$ & $\begin{array}{l}\text { C3: Contig38361 } \\
\text { C5: Contig49537 }\end{array}$ & $58-97$ & {$[1.2 / 0.8]$} & No & Ren et al. (2001) \\
\hline Catsper3 & $\begin{array}{l}\text { Sperm-specific calcium channel } \\
\text { involved in sperm motility }\end{array}$ & $\begin{array}{l}\text { C3: Contig50793 } \\
\text { C5: Contig16275 }\end{array}$ & $61-96$ & {$[0.1 / 0.3]$} & No & Ren et al. (2001) \\
\hline Catsper4 & $\begin{array}{l}\text { Sperm-specific calcium channel } \\
\text { involved in sperm motility }\end{array}$ & $\begin{array}{l}\text { C3: Contig119271 } \\
\text { C5: Contig251057 }\end{array}$ & $\begin{array}{l}\text { 41-74 } \\
\text { (4: against } \\
\text { Ciona } \\
\text { intestinalis) }\end{array}$ & {$[0.7 / 1.0]$} & No & Ren et al. (2001) \\
\hline suREJ1 & $\begin{array}{l}\text { Sperm receptor for egg jelly, } \\
\text { involved in activation of } \\
\text { acrosome reaction }\end{array}$ & $\begin{array}{l}\text { C3: Contig31292 } \\
\text { C5: Contig12876 }\end{array}$ & $45-19$ & {$[1.2 / 2]$} & No & $\begin{array}{l}\text { Vacquier \& Moy } \\
\text { (1997) }\end{array}$ \\
\hline Bindin & $\begin{array}{l}\text { Sperm protein involved in } \\
\text { attachment with egg vitelline } \\
\text { envelope and fusion of sperm-- } \\
\text { egg membranes }\end{array}$ & $\begin{array}{l}\text { C3: Contig72545 } \\
\text { C5: Contig18807 }\end{array}$ & $62-20$ & {$[0.5 / 1]$} & No & $\begin{array}{l}\text { Vacquier \& Moy } \\
\text { (1997) }\end{array}$ \\
\hline EBR1 & Egg bindin receptor & $\begin{array}{l}\text { C3: Contig41363_bb } \\
\text { C5: Contig } 41363\end{array}$ & $45-4$ & {$[1.2 / 1.3]$} & No & $\begin{array}{l}\text { Kamei \& Glabe } \\
\text { (2003) }\end{array}$ \\
\hline $\mathrm{Obi1}^{\#}$ & $\begin{array}{l}\text { Egg receptor for sperm in Patiria } \\
\text { miniata }\end{array}$ & $\begin{array}{l}\text { C3: Contig63504 } \\
\text { C5: Contig9261 }\end{array}$ & $39-25$ & {$[0.5 / 0.3]$} & No & $\begin{array}{l}\text { Hart \& Foster } \\
\text { (2013) }\end{array}$ \\
\hline ARIS1* & $\begin{array}{l}\text { Gene involved in induction of } \\
\text { acrosome reaction in sea stars } \\
\text { (Acrosome Reaction Inducing } \\
\text { Substance) }\end{array}$ & $\begin{array}{l}\text { C3: Contig79388 } \\
\text { C5: no hits }\end{array}$ & $63-10$ & - & - & $\begin{array}{l}\text { Ikadai \& Hoshi } \\
\text { (1981) }\end{array}$ \\
\hline ARIS2* & $\begin{array}{l}\text { Gene involved in induction of } \\
\text { acrosome reaction in sea stars } \\
\text { (Acrosome Reaction Inducing } \\
\text { Substance) }\end{array}$ & $\begin{array}{l}\text { C3: Contig13709 } \\
\text { C5: no hits }\end{array}$ & $58-25$ & - & - & $\begin{array}{l}\text { Ikadai \& Hoshi } \\
\text { (1981) }\end{array}$ \\
\hline ARIS3* & $\begin{array}{l}\text { Gene involved in induction of } \\
\text { acrosome reaction in sea stars } \\
\text { (Acrosome Reaction Inducing } \\
\text { Substance) }\end{array}$ & $\begin{array}{l}\text { C3: Contig69716 } \\
\text { C5: no hits }\end{array}$ & $54-44$ & - & - & $\begin{array}{l}\text { Ikadai \& Hoshi } \\
\text { (1981) }\end{array}$ \\
\hline Rendezvin & $\begin{array}{l}\text { Gene encoding for egg proteins } \\
\text { involved in organization of } \\
\text { fertilization envelope }\end{array}$ & $\begin{array}{l}\text { C3: Contig123340 } \\
\text { C5: no hits }\end{array}$ & $40-89$ & - & - & $\begin{array}{l}\text { Wong \& Wessel } \\
\text { (2006) }\end{array}$ \\
\hline
\end{tabular}

*Sequences from the sea star Asterias amurensis were used as query sequences.

"Sequence from the sea star Patiria miniata was used as query sequence.

First, positive selection may be a direct consequence of brooding. Indeed, the evolution of brooding causes important changes in the environmental conditions surrounding the eggs. The eggs are gathered into pouches (the bursae) and are therefore present at higher densities than in the open water, and in an 
environment possibly reduced in oxygen (Strathmann \& Chaffee 1984). According to Strathmann \& Chaffee (1984), oxygen is a limiting factor in many situations of brooding or in marine species providing brood protection, and the smaller size of such species with respect to their close relatives could be explained as an adaptation to oxygen availability (Strathmann et al. 1984). As a matter of fact, C3 individuals are on average larger than C5 individuals and reach also larger maximal sizes (Stöhr et al. 2009; Weber et al. 2014). If oxygen levels are lower (or limiting) in the bursae, sperm with enhanced motility might have been positively selected to reach the eggs despite lower oxygen concentrations.

Second, another, indirect consequence of brooding may be an increase in the sexual conflict between males and females regarding the optimal ratio of egg/sperm encounters, due to the risk of polyspermy and its contrasted cost among sexes. This lethal event, occurring when several spermatozoa fertilize the same oocyte, might occur more often if they are present at high density (Dale \& Monroy 1981; Wong \& Wessel 2004). Natural selection would thus favour eggs emitting less (or less efficient) chemical attractants, thereby causing an increase in natural selection for sperm motility.

Third, sperm motility is an important component of sperm competition (Birkhead et al. 1999; Levitan 2000; Gage et al. 2004; Snook 2005). In sea stars, patterns of bindin evolution are contrasted between gonochoric external fertilizers, which are subject to sperm competition, and selfing hermaphrodites (brooders or not), which are not (Patiño et al. 2016). Selfing hermaphrodites displayed no or low evidence of positive selection, whereas external fertilizers displayed numerous sites under positive selection. In O. longicauda, fertilization might occur as a single event within a given brooding chamber (cf above, and Weber et al. 2014). If adult behaviour ensures that sperm from a single male enters a brooding pouch, there will not be any sperm competition. However, without parentage analyses, the possibility that sperm from several males reach a brooding pouch cannot be ruled out. Indeed, multiple paternity was reported in several brooding sea urchins (Chenuil et al. 2004; Maturana et al. 2016). If sperm from several males enter a brooding chamber, competition among males may be increased due to higher gamete concentration, favouring positive selection on sperm motility genes.

Fourth, natural selection may have favoured mutations leading to prezygotic isolation between divergent populations or species to avoid wasting gametes in fertilizations producing unviable or sterile offspring, corresponding to the reinforcement hypothesis (Lessios 2011). According to this hypothesis, when two species diverge in allopatry, their genomes become incompatible whereas their fertilization systems may remain compatible. If hybridization occurs after secondary contact, hybrid embryos may have reduced fitness or may not develop at all, wasting reproductive effort. Consequently, divergent proteins preventing heterospecific fertilization would be positively selected by natural selection. In the case of Ophioderma, hybrids with reduced fitness may have occurred from the two possible types of crosses (C3 sperm with C5 oocytes and C5 sperm with C3 oocytes). Yet, as the cost of gamete loss is presumably higher in the brooding species (due to the higher parental investment observed in this species), selective pressures may have been higher in brooders (particularly in genes expressed in females and eggs, but by co-evolution, also on genes expressed in males and spermatozoa), explaining why positive selection was detected in this lineage. Why positive selection would be detected in sperm motility genes, and not other reproduction genes, has no conspicuous explanation under a strict reinforcement hypothesis. The reality may be a combination of several explanations. It is likely that selection due to the confined fertilizing environment (the first or second explanations) led to rapid evolution of some sperm proteins, which contributed to accelerate prezygotic isolation between brooders and broadcasters.

\section{Sperm chemotaxis: a common mechanism of species recognition in brittle stars?}

Our results suggest for the first time that sperm motility genes could have contributed to prezygotic isolation between closely related echinoderm species. Such an isolation could also have been favoured through chemotaxis differences, as sperm chemotaxis (through the occurrence of different sperm chemoattractants) plays for example an important role in sexual selection in the mussel Mytilus galloprovincialis (Evans et al. 2012). Consistent with this, the brooding and broadcasting species likely display differences in their chemoattractants and related receptors. Indeed, we found that the sperm chemoattractant receptor of O. longicauda C5 displayed nine nonsynonymous mutations and a fourcodon gap in its extracellular (ligand-binding) domain. In contrast, the transmembrane and intracellular domains remained conserved between O. longicauda $\mathrm{C} 3$ and C5.

Previous research showed that sperm chemotaxis is generally not species specific in echinoderms, except for brittle stars. For example, sperm of the sea urchin Lytechinus pictus could successfully be activated by speract chemoattractants of the species Strongyloncentrotus purpuratus (Guerrero et al. 2010). In addition, a 
recent study on speract and its receptor in five species of the sea urchin genus Diadema showed that these molecules evolve under strong purifying selection and not under diversifying selection (Jagadeeshan et al. 2015). Furthermore, sperm chemotaxis appeared to be mostly family specific in 19 species of holothurians (Miller 1997), as well as in six sea star species (Nakachi et al. 2006). In contrast, sperm chemotaxis was species specific in 10 of 15 species of brittle stars (Miller 1997) suggesting that chemoattractants are mostly species specific in brittle stars. In particular, sperm chemotaxis specificity allowed separating two unidentified species belonging to the Macrophiothrix genus. Therefore, mechanisms of species recognition may occur during sperm chemotaxis in brittle stars, contrasting with previous research on marine invertebrates. Research on brittle star sperm-activating peptides, associated receptor and more generally, genes involved in sperm activation should be pursued, as they might be involved in numerous speciation events in this particular class of echinoderms as in other groups of animals.

\section{Acknowledgements}

We are very grateful to Christos Arvanitidis from the Hellenic Center for Marine Research (HCMR, Crete) who hosted us in his laboratory, brought pertinent advice for general organization and organized the sampling sessions. We are also grateful to João Reis and João Rodrigues for logistical help and participation to sampling sessions. We would like to thank the CCMAR Institute of Faro and the Assemble European programme for providing funding for the sampling in Portugal (ASSEMBLE grant agreement no. 227799). JIMB was supported by SNSF grant (3100A0-104005). Many thanks to Thanos Dailianis, Elena Sarropoulou, Magdalini Christodoulou, Frédéric Zuberer, Laurent Vanbostal, Didier Weber and Thi Weber for providing samples or for helping during the sampling sessions. We thank the genomic platform Genotoul (INRA, Toulouse) for transcriptome sequencing. We are very grateful to Pierre Pontarotti who provided computing infrastructure to analyse the data and for fruitful discussions. We also would like to thank Chloé Jeanne Hot for helping using PSGfinder and Walter Salzburger for providing useful comments to improve this manuscript. Finally, we would like to thank two anonymous reviewers for their comments on a previous version of the manuscript.

\section{References}

Baric S, Sturmbauer C (1999) Ecological parallelism and cryptic species in the genus Ophiothrix derived from mitochondrial DNA sequences. Molecular Phylogenetics and Evolution, 11, 157-162.

Beltrán C, Galindo BE, Rodríguez-Miranda E, Sánchez D (2007) Signal transduction mechanisms regulating ion fluxes in the sea urchin sperm. Signal Transduction, 7, 103-117.
Bickford D, Lohman DJ, Sodhi NS et al. (2007) Cryptic species as a window on diversity and conservation. Trends in Ecology \& Evolution, 22, 148-155.

Biermann $\mathrm{CH}$, Marks JA, Vilela-Silva A-CES, Castro MO, Mourão PAS (2004) Carbohydrate-based species recognition in sea urchin fertilization: another avenue for speciation? Evolution \& Development, 6, 353-361.

Birkhead TR, Martinez JG, Burke T, Froman DP (1999) Sperm mobility determines the outcome of sperm competition in the domestic fowl. Proceedings of the Royal Society of London. Series B: Biological Sciences, 266, 1759-1764.

Boissin E, Féral JP, Chenuil A (2008) Defining reproductively isolated units in a cryptic and syntopic species complex using mitochondrial and nuclear markers: the brooding brittle star, Amphipholis squamata (Ophiuroidea). Molecular Ecology, 17, 1732-1744.

Boissin E, Stöhr S, Chenuil A (2011) Did vicariance and adaptation drive cryptic speciation and evolution of brooding in Ophioderma longicauda (Echinodermata: Ophiuroidea), a common Atlanto-Mediterranean ophiuroid? Molecular Ecology, 20, 4737-4755.

Cahais V, Gayral P, Tsagkogeorga G et al. (2012) Reference-free transcriptome assembly in non-model animals from nextgeneration sequencing data. Molecular Ecology Resources, 12, 834-845.

Chenuil A, Gault A, Feral JP (2004) Paternity analysis in the Antarctic brooding sea urchin Abatus nimrodi. A pilot study. Polar Biology, 27, 177-182.

Chevreux B, Wetter T, Suhai S et al. (1999) Genome sequence assembly using trace signals and additional sequence information. German Conference on Bioinformatics, 99, 45-56.

Conesa A, Götz S, García-Gómez JM et al. (2005) Blast2GO: a universal tool for annotation, visualization and analysis in functional genomics research. Bioinformatics, 21, 3674-3676.

Dale B, Monroy A (1981) How is polyspermy prevented? Gamete Research, 4, 151-169.

Dangott LJ, Garbers DL (1984) Identification and partial characterization of the receptor for speract. Journal of Biological Chemistry, 259, 13712-13716.

Darszon A, Guerrero A, Galindo BE, Nishigaki T, Wood CD (2008) Sperm-activating peptides in the regulation of ion fluxes, signal transduction and motility. The International Journal of Developmental Biology, 52, 595-606.

Ellegren H (2014) Genome sequencing and population genomics in non-model organisms. Trends in Ecology \& Evolution, 29, 51-63.

Evans JP, Sherman CDH (2013) Sexual selection and the evolution of egg-sperm interactions in broadcast-spawning invertebrates. The Biological Bulletin, 224, 166-183.

Evans JP, Garcia-Gonzalez F, Almbro M, Robinson O, Fitzpatrick JL (2012) Assessing the potential for egg chemoattractants to mediate sexual selection in a broadcast spawning marine invertebrate. Proceedings of the Royal Society B: Biological Sciences, 279, 2855-2861.

Fenaux L (1969) Le développement larvaire chez Ophioderma longicauda (Retzius). Cahiers de Biologie Marine, 10, 59-62.

Fenaux L (1972) Evolution saisonnière des gonades chez l'Ophiure Ophioderma longicauda (Retzius), Ophiuroidea. Internationale Revue der gesamten Hydrobiologie und Hydrographie, 57, 257-262. 
Gage MJG, Macfarlane CP, Yeates S et al. (2004) Spermatozoal traits and sperm competition in Atlantic salmon: relative sperm velocity Is the primary determinant of fertilization success. Current Biology, 14, 44-47.

Galindo BE, de la Vega-Beltrán JL, Labarca P, Vacquier VD, Darszon A (2007) Sp-tetraKCNG: a novel cyclic nucleotide gated K+ channel. Biochemical and Biophysical Research Communications, 354, 668-675.

Gayral P, Weinert L, Chiari Y et al. (2011) Next-generation sequencing of transcriptomes: a guide to RNA isolation in nonmodel animals. Molecular Ecology Resources, 11, 650-661.

Gayral P, Melo-Ferreira J, Glémin S et al. (2013) Reference-free population genomics from next-generation transcriptome data and the vertebrate-invertebrate gap. PLoS Genetics, 9, e1003457. doi: 10.1371/journal.pgen.1003457.

Guerrero A, Nishigaki T, Carneiro J et al. (2010) Tuning sperm chemotaxis by calcium burst timing. Developmental Biology, 344, 52-65.

Hansbrough JR, Garbers DL (1981) Speract. Purification and characterization of a peptide associated with eggs that activates spermatozoa. Journal of Biological Chemistry, 256, 14471452.

Hart MW (2013) Structure and evolution of the sea star egg receptor for sperm bindin. Molecular Ecology, 22, 2143-2156.

Hart MW, Foster A (2013) Highly expressed genes in gonads of the bat star Patiria miniata: gene ontology, expression differences, and gamete recognition loci. Invertebrate Biology, 132, 241-250

Hart MW, Sunday JM, Popovic I, Learning KJ, Konrad CM (2014) Incipient speciation of sea star populations by adaptive gamete recognition coevolution. Evolution, 68, 1294-1305.

Heimeier D, Lavery S, Sewell MA (2010) Molecular species identification of Astrotoma agassizii from planktonic embryos: further evidence for a cryptic species complex. Journal of Heredity, 101, 775-779.

Hendler G (1991) Reproduction of Marine Invertebrates. Pacific Grove, California.

Hirohashi N, Kamei N, Kubo H et al. (2008) Egg and sperm recognition systems during fertilization. Development, Growth $\mathcal{E}$ Differentiation, 50, 221-238.

Hoareau TB, Boissin E, Paulay G, Bruggemann JH (2013) The Southwestern Indian Ocean as a potential marine evolutionary hotspot: perspectives from comparative phylogeography of reef brittle-stars. Journal of Biogeography, 40, 2167-2179.

Huang X, Madan A (1999) CAP3: a DNA sequence assembly program. Genome Research, 9, 868-877.

Hughes AR, Inouye BD, Johnson MTJ, Underwood N, Vellend M (2008) Ecological consequences of genetic diversity. Ecology Letters, 11, 609-623.

Hunter RL, Halanych KM (2008) Evaluating connectivity in the brooding brittle star Astrotoma agassizii across the Drake passage in the Southern Ocean. Journal of Heredity, 99, 137148.

Ikadai H, Hoshi M (1981) Biochemical studies on the acrosome reaction of the starfish, Asterias Amurensis II. Purification and characterization of acrosome reaction-inducing substance. Development, Growth \& Differentiation, 23, 81-88.

Jagadeeshan S, Coppard SE, Lessios HA (2015) Evolution of gamete attraction molecules: evidence for purifying selection in speract and its receptor, in the pantropical sea urchin Diadema. Evolution \& Development, 17, 92-108.
Kamei N, Glabe CG (2003) The species-specific egg receptor for sea urchin sperm adhesion is EBR1, a novel ADAMTS protein. Genes \& Development, 17, 2502-2507.

Langmead B, Salzberg SL (2012) Fast gapped-read alignment with Bowtie 2. Nature Methods, 9, 357-359.

Lessios HA (2011) Speciation genes in free-spawning marine invertebrates. Integrative and Comparative Biology, 51, 456-465.

Levitan DR (2000) Sperm velocity and longevity trade off each other and influence fertilization in the sea urchin Lytechinus variegatus. Proceedings of the Royal Society of London. Series B: Biological Sciences, 267, 531-534.

Li H, Durbin R (2009) Fast and accurate short read alignment with Burrows-Wheeler transform. Bioinformatics, 25, 1754 1760.

MacArthur RH, Wilson EO (1967) The theory of island biogeography. In: Monographs in Population Biology (eds. MacArthur RH, Wilson EO). Princeton Univ. Press, Princeton, New Jersey.

Mah SA, Swanson WJ, Vacquier VD (2005) Positive selection in the carbohydrate recognition domains of sea urchin sperm receptor for egg jelly (suREJ) proteins. Molecular Biology and Evolution, 22, 533-541.

Maturana CS, Gérard K, Díaz A, David B, Féral JP, Poulin E (2016) Mating system and evidence of multiple paternity in the Antarctic brooding sea urchin Abatus agassizii. Polar Biology, 39, 1-11.

Mercier A, Hamel J-F (2009) Advances in Marine Biology: Endogenous and Exogenous Control of Gametogenesis and Spawning in Echinoderms. Academic Press, London.

Miller RL (1997) Specificity of sperm chemotaxis among great barrier reef shallow-water Holothurians and Ophiuroids. Journal of Experimental Zoology, 279, 189-200.

de Moura Barboza CA, Mattos G, Paiva PC (2015) Brittle stars from the Saint Peter and Saint Paul Archipelago: morphological and molecular data. Marine Biodiversity Records, 8, 1-9.

Murrell B, Weaver S, Smith MD et al. (2015) Gene-wide identification of episodic selection. Molecular Biology and Evolution, 32, 1365-1371.

Muths D, Davoult D, Gentil F, Jollivet D (2006) Incomplete cryptic speciation between intertidal and subtidal morphs of Acrocnida brachiata (Echinodermata: Ophiuroidea) in the Northeast Atlantic. Molecular Ecology, 15, 3303-3318.

Muths D, Jollivet D, Gentil F, Davoult D (2009) Large-scale genetic patchiness among NE Atlantic populations of the brittle star Ophiothrix fragilis. Aquatic Biology, 5, 117-132.

Nakachi M, Moriyama H, Hoshi M, Matsumoto M (2006) Acrosome reaction is subfamily specific in sea star fertilization. Developmental Biology, 298, 597-604.

Nakachi M, Hoshi M, Matsumoto M, Moriyama H (2008) Conserved sequences of sperm-activating peptide and its receptor throughout evolution, despite speciation in the sea star Asterias amurensis and closely related species. Zygote, 16, 229237.

Naughton KM, O'Hara TD, Appleton B, Cisternas PA (2014) Antitropical distributions and species delimitation in a group of ophiocomid brittle stars (Echinodermata: Ophiuroidea: Ophiocomidae). Molecular Phylogenetics and Evolution, 78, 232-244.

Noor MAF, Feder JL (2006) Speciation genetics: evolving approaches. Nature Reviews Genetics, 7, 851-861. 
Nosil P, Feder JL (2012) Genomic divergence during speciation: causes and consequences. Philosophical transactions of the Royal Society B, 367, 332-342.

Nosil P, Schluter D (2011) The genes underlying the process of speciation. Trends in Ecology \& Evolution, 26, 160-167.

O'Hara TD, Byrne M, Cisternas PA (2004) The Ophiocoma erinaceus complex: another case of cryptic speciation in echinoderms. Echinoderms: München. In: Proceedings of the 11th International Echinoderm Conference, pp. 537-542.

Palumbi SR (1994) Genetic divergence, reproductive isolation, and marine speciation. Annual Review of Ecology and Systematics, 25, 547-572.

Patiño S, Keever CC, Sunday JM et al. (2016) Sperm bindin divergence under sexual selection and concerted evolution in sea stars. Molecular Biology and Evolution, 33, 1988-2001.

Pérez-Portela R, Almada V, Turon X (2013) Cryptic speciation and genetic structure of widely distributed brittle stars (Ophiuroidea) in Europe. Zoologica Scripta, 42, 151-169.

Podlaha O, Zhang J (2003) Positive selection on protein-length in the evolution of a primate sperm ion channel. Proceedings of the National Academy of Sciences, 100, 12241-12246.

Podlaha O, Webb DM, Tucker PK, Zhang J (2005) Positive selection for indel substitutions in the rodent sperm protein Catsper1. Molecular Biology and Evolution, 22, 18451852.

Pond SLK, Muse SV (2005) HyPhy: hypothesis testing using phylogenies. In: Statistical Methods in Molecular Evolution (ed. Nielsen R), pp. 125-181. Springer, New York.

Pond SLK, Murrell B, Fourment $\mathrm{M}$ et al. (2011) A random effects branch-site model for detecting episodic diversifying selection. Molecular Biology and Evolution, 28, 3033-3043.

Ren D, Navarro B, Perez G et al. (2001) A sperm ion channel required for sperm motility and male fertility. Nature, 413, 603-609.

Reusch TBH, Ehlers A, Hämmerli A, Worm B (2005) Ecosystem recovery after climatic extremes enhanced by genotypic diversity. Proceedings of the National Academy of Sciences of the United States of America, 102, 2826-2831.

Romiguier J, Gayral P, Ballenghien M et al. (2014) Comparative population genomics in animals uncovers the determinants of genetic diversity. Nature, 515, 261-263.

Sarah G, Homa F, Pointet S et al. (2016) A large set of 26 new reference transcriptomes dedicated to comparative population genomics in crops and wild relatives. Molecular Ecology Resources, doi: 10.1111/1755-0998.12587.

Seehausen O, Butlin RK, Keller I et al. (2014) Genomics and the origin of species. Nature Reviews Genetics, 15, 176-192.

Simpson JT, Wong K, Jackman SD et al. (2009) ABySS: a parallel assembler for short read sequence data. Genome Research, 19, 1117-1123.

Snook RR (2005) Sperm in competition: not playing by the numbers. Trends in Ecology \& Evolution, 20, 46-53.

Sponer R, Roy MS (2002) Phylogeographic analysis of the brooding brittle star Amphipholis Squamata (Echinodermata) along the coast of New Zealand reveals high cryptic genetic variation and cryptic dispersal potential. Evolution, 56, 1954 1967.

Stöhr S, Muths D (2010) Morphological diagnosis of the two genetic lineages of Acrocnida brachiata (Echinodermata: Ophiuroidea), with description of a new species. Journal of the
Marine Biological Association of the United Kingdom, 90, 831843.

Stöhr S, Boissin E, Chenuil A (2009) Potential cryptic speciation in Mediterranean populations of Ophioderma (Echinodermata: Ophiuroidea). Zootaxa, 2071, 1-20.

Stöhr S, O'Hara TD, Thuy B (2012) Global diversity of brittle stars (Echinodermata: Ophiuroidea). PLoS ONE, 7, e31940. doi: 10.1371/journal.pone.0031940.

Strathmann RR, Chaffee C (1984) Constraints on egg masses. II. Effect of spacing, size, and number of eggs on ventilation of masses of embryos in jelly, adherent groups, or thin-walled capsules. Journal of Experimental Marine Biology and Ecology, 84, 85-93.

Strathmann RR, Strathmann MF, Emson RH (1984) Does limited brood capacity link adult size, brooding, and simultaneous hermaphroditism? A test with the starfish Asterina phylactica. The American Naturalist, 123, 796-818.

Sunday JM, Hart MW (2013) Sea star populations diverge by positive selection at a sperm-egg compatibility locus. Ecology and Evolution, 3, 640-654.

Taboada S, Pérez-Portela R (2016) Contrasted phylogeographic patterns on mitochondrial DNA of shallow and deep brittle stars across the Atlantic-Mediterranean area. Scientific Reports, 6, 32425. doi: 10.1038/srep32425.

Vacquier VD (1998) Evolution of gamete recognition proteins. Science, 281, 1995-1998.

Vacquier VD, Moy GW (1997) The fucose sulfate polymer of egg jelly binds to sperm REJ and is the inducer of the sea urchin sperm acrosome reaction. Developmental Biology, 192, 125-135.

Vacquier VD, Swanson WJ (2011) Selection in the rapid evolution of gamete recognition proteins in marine invertebrates. Cold Spring Harbor Perspectives in Biology, 3, a002931. doi: $10.1101 /$ cshperspect.a002931.

Walsh P, Metzger D, Higuchi R (1991) Chelex 100 as a medium for simple extraction of DNA for PCR-based typing from forensic material. BioTechniques, 10, 506-513.

Wang D, King SM, Quill TA, Doolittle LK, Garbers DL (2003) A new sperm-specific $\mathrm{Na}+/ \mathrm{H}+$ Exchanger required for sperm motility and fertility. Nature Cell Biology, 5, 1117-1122.

Weber AA-T (2015) Etude écologique et génétique du complexe d'espèces cryptiques Ophioderma longicauda (Ophiuroidea: Echinodermata): Comparaison entre lignées incubantes et lignées produisant des larves planctoniques. Aix-Marseille Université, Marseille.

Weber AA-T, Dupont S, Chenuil A (2013) Thermotolerance and regeneration in the brittle star species complex Ophioderma longicauda: a preliminary study comparing lineages and Mediterranean basins. Comptes Rendus Biologies, 336, 572-581.

Weber AA-T, Stöhr S, Chenuil A (2014) Genetic data, reproduction season and reproductive strategy data support the existence of biological species in Ophioderma longicauda. Comptes Rendus Biologies, 337, 553-560.

Weber AA-T, Mérigot B, Valière S, Chenuil A (2015) Influence of the larval phase on connectivity: strong differences in the genetic structure of brooders and broadcasters in the Ophioderma longicauda species complex. Molecular Ecology, 24, 6080-6094.

Wong JL, Wessel GM (2004) Major components of a sea urchin block to polyspermy are structurally and functionally conserved. Evolution \& Development, 6, 134-153. 
Wong JL, Wessel GM (2006) Rendezvin: an essential gene encoding independent, differentially secreted egg proteins that organize the fertilization envelope proteome after selfassociation. Molecular Biology of the Cell, 17, 5241-5252.

Yang Z (2007) PAML 4: phylogenetic analysis by maximum likelihood. Molecular Biology and Evolution, 24, 1586-1591.

Yang Z, Nielsen R (2000) Estimating synonymous and nonsynonymous substitution rates under realistic evolutionary models. Molecular Biology and Evolution, 17, 32-43.

A.A.-T.W., L.A.-R. and A.C. designed research; A.A.T.W. performed sampling and laboratory work; A.A.T.W., L.A.-R., N.G., A.B. and J.I.M.-B. analysed the data; A.A.-T.W., L. A.-R. and A.C. wrote the manuscript; all authors contributed to the final version of the manuscript.

\section{Data accessibility}

The raw transcriptome reads were deposited on the Sequence Read Archive (SRA) (Accession no.: SRP096095) under the BioProject PRJNA360063. The assembled transcriptomes of Ophioderma longicauda C3 and C5 and all the alignments listed in Tables 3 and 4 are available from the Dryad Digital Repository: http:/ / dx.doi.org/10.5061/dryad.713q3.

\section{Supporting information}

Additional supporting information may be found in the online version of this article.

Table S1 Details of sampling localities, dates and individuals used in this study.

Table S2 BLASTP search for 37 positively selected genes between $\mathrm{O}$. longicauda $\mathrm{C} 3$ and $\mathrm{C} 5$ that did not display GO term annotations.

Fig. S1 A: Neighbor-Joining tree of the mitochondrial marker $\mathrm{COI}$ for the five O. longicauda $\mathrm{C} 3$ individuals and two O. longicauda C5 individuals. B: Neighbor-Joining tree of the nuclear marker EF1 for the five O. longicauda C3 individuals and two O. longicauda C5 individuals.

Fig. S2 Results of Blast2Go annotation (Level 3) of 5925 orthologs of Ophioderma longicauda C3 and C5 species. 